\title{
Meiofauna in stream habitats: temporal dynamics of abundance, biomass and secondary production in different substrate microhabitats in a first-order stream
}

\author{
Henrike Brüchner-Hüttemann (iD) Christoph Ptatscheck • Walter Traunspurger
}

Received: 18 April 2020/Accepted: 20 August 2020/Published online: 3 September 2020

(C) The Author(s) 2020

\begin{abstract}
Meiofaunal abundance, biomass and secondary production were investigated over 13 months in an unpolluted first-order stream. Four microhabitats were considered: sediment and the biofilms on dead wood, macrophytes and leaf litter. The relative contribution of the microhabitats to secondary production and the influence of environmental factors on meiofaunal density distribution were estimated. We expected (1) meiofaunal abundance and biomass to exhibit seasonal patterns, with more pronounced seasonal fluctuations on macrophytes and leaf litter than in the other microhabitats, (2) annual secondary production to be highest in sediment; however, the relative contribution of the microhabitats to monthly secondary production would change during the year, and (3) a bottom-up driven influence on meiofaunal density distribution in the microhabitats. Meiofaunal annual mean abundance, biomass and secondary production were 7-14 times higher in sediment and on dead wood than on macrophytes and leaf litter. Significant seasonal patterns described the meiofaunal abundance in sediment and on leaf litter as well as the biomass in sediment, on macrophytes and leaf litter.
\end{abstract}

Handling Editor: Télesphore Sime-Ngando.

H. Brüchner-Hüttemann $(\bowtie) \cdot$ C. Ptatscheck ·

W. Traunspurger

Animal Ecology, Bielefeld University, Konsequenz 45,

33615 Bielefeld, Germany

e-mail: henrike.bruechner-huettemann@uni-bielefeld.de
Organisms in sediment and on dead wood contributed 48 and $43 \%$, respectively, to secondary production $\mathrm{m}^{-2}$, but in regard to the stream area covered by the microhabitats, sediment had the highest share (80\%). Significant determinants of the density distribution were AFDM, protozoans, bacteria and Chl-a, which influenced all meiofaunal groups. Our study clearly indicates that meiofaunal organisms in sediment and on dead wood have a remarkable share on total secondary production of lotic systems which is especially relevant for forested low-order streams.

Keywords Sediment - Dead wood - Macrophytes · Leaf litter $\cdot$ Seasonal pattern

\section{Introduction}

Headwater streams provide unique aquatic habitats not present elsewhere in a river network (Wohl 2017). Knowledge about the biological and ecological function of those first- and second-order streams (Strahler 1952) is important for the understanding of the whole stream system, because headwaters make up 70-80\% of the total lengths of river networks (Downing et al. 2012; Wohl 2017).

Headwater streams are not static, but dynamic, constantly shifting mosaics of interconnected microhabitats. Those microhabitats are established by 
different organic and mineral surfaces, such as the sediment or macrophytes growing in the stream, as well as dead wood, and leaf litter entering the stream (Allan and Castillo 2007). In small headwater streams surrounded by forest, the entry of coarse organic material is higher and dead wood and leaf litter are of greater importance than in larger streams (Vannote et al. 1980; Richardson and Danehy 2007). The input of such organic matter and the growth of macrophytes as well as the discharge underly temporal dynamics that occur on scales lasting from days to years (Hildrew and Giller 1994; Robertson 2000; Leung et al. 2012). Thus, the variable flow rates, which are influenced by changes in discharge caused by, for example, heavy rain falls or dry periods, the unstable patch configurations and seasonal changes over the course of a year create a both spatially and temporally heterogeneous environment (Palmer et al. 2000; Robertson 2000; Wohl 2017).

As different microhabitats provide refuges by buffering against unfavorable conditions, the heterogeneity of microhabitat is a crucial factor regulating the dynamics of faunal occurrence in streams (Townsend 1989; Gordon et al. 2004). The availability and abundance of microhabitats that can act as flow refugia as well as the spatial arrangement of them in flowing waters are important for the persistence of invertebrate populations (Hildrew et al. 1991; Palmer et al. 1992, 2000). This is especially the case for small invertebrates, such as those of meiofaunal size. Although some meiofauna groups, e.g., rotifers and copepods, are able to migrate vertically deeper in the sediment at high flows, they are at risk of passive downstream displacement even with modest flooding (Palmer et al. 1992).

Meiofauna (motile invertebrates that pass through a sieve of 500- $\mu \mathrm{m}$ mesh size but are retained on one with a 44- $\mu \mathrm{m}$ mesh size; Giere 2009) comprises an abundant and diverse group that dominates benthic communities of metazoa in freshwater systems (Robertson et al. 2000; Traunspurger 2000; SchmidAraya et al. 2002). Investigations of different European streams have shown that meiofauna can account for $58-82 \%$ of the entire invertebrate diversity (Robertson et al. 2000) and for up to $51 \%$ of total invertebrate production in sediment of an acidic, oligotrophic stream (Stead et al. 2005). Thus, due to their short lifespan, rapid reproduction and numerical dominance, meiofauna plays important roles in aquatic environments and contribute significantly to the secondary production of benthic metazoans (Bergtold and Traunspurger 2005; Stead et al. 2003; Reiss and Schmid-Araya 2008, 2010; Majdi et al. 2017; Schmid-Araya et al. 2020).

Potential food sources for lotic meiofauna are detritus, algae, bacteria and protozoans (Perlmutter and Meyer 1991; Arndt 1993; Borchardt and Bott 1995; Schmid-Araya and Schmid 2000; Majdi and Traunspurger 2015; Weitere et al. 2018; Majdi et al. 2020). In turn, they serve as prey for, e.g., macrofauna organisms like chironomid larvae (Ptatscheck et al. 2017), flatworms (Beier et al. 2004; Kreuzinger-Janik et al. 2018), crustaceans (Weber and Traunspurger 2016, 2017), as well as for juvenile fish (Weber and Traunspurger 2015), thus representing a major trophic link within the food web between the microfauna and larger invertebrates and vertebrates (reviewed by Ptatscheck et al. 2020).

The availability of food sources is a driver of the small-scale spatial patters of meiofaunal communities in lotic systems (Swan and Palmer 2000) and Silver et al. (2002) showed a positive relationship between organic matter and the densities of macro- and meiofauna. However, conflicting evidence was obtained in other studies (Tod and Schmid-Araya 2009; Gansfort et al. 2018).

Other determinants of meiofaunal microdistribution are biological interactions like predation, but also abiotic factors like oxygen content, stream flow as well as habitat architecture and seasonal influences can alter meiofaunal communities (Palmer et al. 2000; Swan and Palmer 2000; Teiwes et al. 2007). Nevertheless, there is still little knowledge about the biotic and abiotic factors (e.g., potential food sources, nutrient status of the stream) that influence meiofaunal communities within different microhabitats.

Previous studies have shown that stream meiofaunal numbers typically reach a peak in spring and summer (Palmer 1990; Beier and Traunspurger 2003; Reiss and Schmid-Araya 2008). However, most investigations dealing with seasonal patterns of meiofaunal abundance have been limited to the sediment (e.g., Palmer 1990; Beier and Traunspurger 2003; Stead et al. 2005; Reiss and Schmid-Araya 2008) or macrophytes (e.g., Suren 1992; Tod and SchmidAraya 2009), and also, the assessments of annual meiofaunal secondary production in streams have likewise included those two microhabitats (Stead et al. 
2005; Tod and Schmid-Araya 2009; Reiss and Schmid-Araya 2010; Majdi et al. 2017). Nevertheless, to understand the transfer of energy and material in streams the investigation of secondary production is essential (Schmid-Araya et al. 2020) whereby habitatspecific production patterns of different microhabitats are needed. For example, the high production rates of the periphyton (i.e., attached micro-communities) on stony hard substrates demonstrate the importance of this meiofaunal microhabitat, as determined in a study of three Swedish lakes (Schroeder et al. 2012). Moreover, studies of dead wood in flowing waters prove that macrofaunal invertebrates and unicellular organisms colonizing this habitat have a considerable amount on secondary production of the system (Benke et al. 1985; Brüchner-Hüttemann et al. 2019).

Given that the ecological importance of meiofauna in freshwater habitats begins with the ability of these organisms to colonize essentially all submerged surfaces, in the present work we investigated the abundance, biomass and secondary production of a meiofaunal community over a 1-year period in four microhabitats (in sediment, as well as on the surfaces of dead wood, macrophytes and leaf litter) of a single first-order stream (Furlbach, Germany). Our study also examined the contribution of the different habitats to the total meiofaunal secondary production of the system and the effects of biotic and abiotic factors on meiofaunal density distribution within the four microhabitats. Specifically, we hypothesized that (1) meiofaunal abundance and biomass in the habitats of the Furlbach would exhibit seasonal patterns. We assumed that in direct comparison of the habitats, seasonal fluctuations will be much more pronounced on macrophytes and leaf litter because these habitats themselves are strongly impacted by seasonal changes (e.g., growth periods and leaf shedding). We hypothesized that (2) total annual secondary production would be highest in sediment because as a subsurface habitat it provides better protection against predation; however, the relative contribution of the different microhabitats to monthly secondary production would change during the year. We expected that (3) in all microhabitats food resources (e.g., organic matter and bacteria) would influence meiofaunal density distribution, which would thus be bottom-up driven.

\section{Materials and methods}

Study site

The Furlbach is a reference stream of the German Federal Environment Agency for type 14, the sandbottomed lowland rivers (Pottgießer and Sommerhäuser 1999). It originates from a marshy seepage spring in a protected area in Augustdorf, North RhineWestphalia, Germany (Fig. 1), where a mosaic of wetlands and sand fields from morainal deposits characterize the landscape. The Furlbachs streambed consists of fine sand with $98 \%$ contribution of a grain size of 60-600 $\mu \mathrm{m}$. Nasturtium officinale (R.Br.) and Berula erecta (Huds.) are the only macrophytes occurring at the sampling site. Sampling for this study took place at an approximately $20-\mathrm{m}$ reach of the Furlbach, $450 \mathrm{~m}$ downstream from the seepage spring, where the Furlbach is surrounded by broad-leafed trees, including black alder (Alnus glutinosa), downy birch (Betula pubescens), sycamore maple (Acer pseudoplatanus) and hornbeam (Carpinus betulus). At the sampling site, the Furlbach is approximately

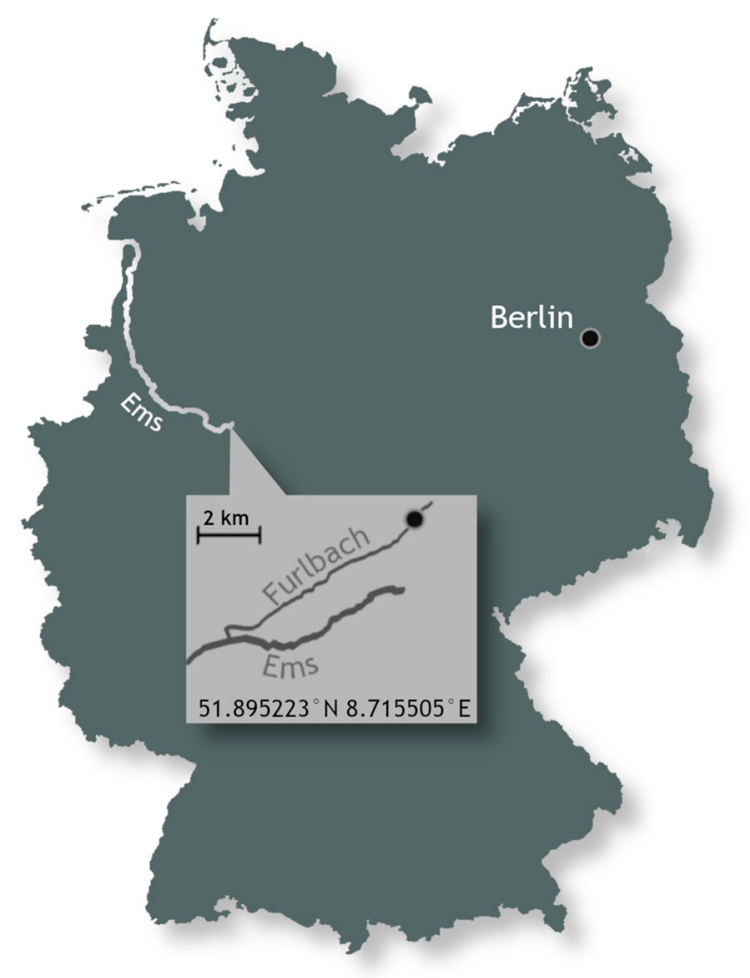

Fig. 1 Map showing the location of the Furlbach in Germany with the coordinates of the sampling site 
1-2 m wide. Throughout the year of sampling, water depth was always between 5 and $20 \mathrm{~cm}$ with an annual mean flow velocity of $0.3 \pm 0.06 \mathrm{~m} \mathrm{~s}^{-1}$ (mean \pm $\mathrm{SD}, n=13)$.

\section{Sampling}

Sampling took place monthly from April 2016 to April 2017 at the above-described 20-m stream reach. At every sampling occasion, the physicochemical data at the sampling site, including temperature $\left({ }^{\circ} \mathrm{C}\right), \mathrm{O}_{2}(\mathrm{mg}$ $\left.\mathrm{L}^{-1}\right)$, conductivity $\left(\mu \mathrm{S} \mathrm{cm}{ }^{-1}\right)$ and $\mathrm{pH}$, were collected using a multi-probe (Multi 3430, WTW, Weilheim, Germany) and the phosphate and nitrate concentrations of the stream water were analyzed. Additionally, $5 \mathrm{~L}$ of stream water was collected in a plastic canister and filtered in the laboratory through $0.2-\mu \mathrm{m}$ cellulose nitrate membrane filters (Whatman, Little Chalfont, Buckinghamshire, UK) for the analysis of unicellular organisms (please see below). This water is hereafter referred to as "filtered stream water."

Samples from four microhabitats (sediment, dead wood, the macrophyte $N$. officinale and leaf litter) were taken at each sampling occasion. Each of the four microhabitats was sampled in four replicates, with one replicate taken approximately every $5 \mathrm{~m}$ along the 20-m stream reach. All samples taken at the sampling site were stored in a cooling box and brought to Bielefeld University.

From each replicate, meiofauna was analyzed. Moreover, the microhabitat-specific abundances of protozoans (flagellates and ciliates) and bacteria, and the amounts of organic material (analyzed as ash-free dry mass, AFDM) and chlorophyll-a (Chl-a) were analyzed.

For details about the analysis of phosphate, nitrate, AFDM and Chl-a as well as of the abundances of unicellular organisms in the stream water and microhabitats, respectively, please refer to Brüchner-Hüttemann et al. (2019).

Sediment: The upper $2 \mathrm{~cm}$ of sediment was sampled with a corer $(3.3 \mathrm{~cm}$ diameter). Per replicate three cores (area $25.66 \mathrm{~cm}^{2}$, total of $51.3 \mathrm{~mL}$ sediment) were taken next to each other randomly from sandbanks and pooled in 100-mL PET bottles. This procedure was chosen to guarantee an appropriate amount of material for the different analyses, and as meiofauna distribution may be affected by small-scale variability (Silver et al. 2002), pooling randomly chosen samples minimize the effect of small-scale heterogeneity. In the laboratory, subsamples for the analysis of the accompanying parameters (abundances of protozoans and bacteria, AFDM, Chl-a) were prepared (see Brüchner-Hüttemann et al. 2019). Meiofaunal organisms were then extracted from the rest of each sediment sample $(45.3 \mathrm{~mL})$ by density centrifugation with LudoxTM50 (Sigma-Aldrich, Munich, Germany; $1.14 \mathrm{~g} \mathrm{~mL}^{-1}$, mesh size $10 \mu \mathrm{m}$ ) according to Pfannkuche and Thiel (1988). Meiofaunal samples from all microhabitats were stained with Rose Bengal (300 $\mu \mathrm{g} \mathrm{mL}^{-1}$; AppliChem, Darmstadt, Germany), fixed with $37 \%$ formalin (final concentration $4 \%$ ) and stored at $20{ }^{\circ} \mathrm{C}$ until counted.

Dead wood: A brush sampler [ $2 \mathrm{~cm}$ diameter; for detailed description of the sampler, see Peters et al. (2005)] was used to sample the biofilm on the surface of dead wood. This sampler scrapes off a defined area $\left(3.14 \mathrm{~cm}^{2}\right)$ on hard substrates and collects all material via a syringe-like construction without loss and contamination, including biofilm-dwelling meiofaunal organisms (Peters et al. 2007; Schroeder et al. 2012). Two adjacent samples from the same trunk were taken for each replicate and pooled in $250-\mathrm{mL}$ PET bottles to yield an appropriate amount of material and to minimize the effect of small-scale heterogeneity (Peters et al. 2007). In the laboratory, filtered stream water was used to bring the volume of all biofilm samples to $150 \mathrm{~mL}$. After homogenization of the samples, subsamples for the accompanying parameters were prepared and the remainder $(106 \mathrm{~mL})$ was used to count meiofauna.

Macrophytes: For macrophyte analyses, per replicate the upper parts of five to eight plant stands of $N$. officinale completely covered by water were sliced off and carefully transferred under water into a white photo tray. This procedure was chosen to guarantee an appropriate amount of material for the analyses. To detach meiofauna, the plant parts were thoroughly rinsed over a $10-\mu \mathrm{m}$ mesh directly in the field. The material left on the mesh was then transferred to 250-mL PET bottles filled with stream water. The rinsed plant material from every replicate was kept separately in plastic bags until its transfer to the laboratory, where the plant parts were scanned and the respective surface area of every replicate was calculated using the program ImageJ [version 1.51f, (Rasband 1997-2018)]. 
Leaf litter: For leaf litter analyses, five to eight randomly chosen leaves per replicate completely covered by water were carefully transferred under water into a photo tray. This procedure was chosen to guarantee an appropriate amount of material for the analyses. The detachment of meiofaunal organisms and the further processing of the sampled leaves (storage, scanning) were then performed the same way as for the macrophytes samples.

\section{Counting}

The number of meiofaunal organisms (nematodes, rotifers, gastrotrichs, tardigrades, ostracods and copepods and their nauplii larvae as permanent meiofauna as well as oligochaetes, microturbellarians, cladocerans and chironomids as representatives of temporary meiofauna, because their body dimensions may increase to within the macrofaunal range) from all microhabitats was determined by microscopy, using an Olympus SZ40 stereo-microscope (Shinjuku, Tokyo, Japan) at $40 \times$ magnification. Meiofauna was identified to higher taxonomic units, and body length and, if necessary, width and height were measured.

\section{Calculation of biomass and secondary production}

After the meiofauna had been counted, their biomass was calculated and expressed as dry weight (dw, $\mathrm{mg} \mathrm{m}^{-2}$ ). The methods used to calculate biomass are summarized in Table 1 and were based on the assumption of a carbon content of $40 \%$, a specific gravity of 1.13 and a dry weight to wet weight ratio of 0.25 (Feller and Warwick 1988). The only exception was rotifers, for which a specific gravity of 1.00 and a dry-to-wet weight ratio of 0.05 (McCauley 1984) was used in the calculations.

The secondary production of every meiofaunal group was calculated using the Plante and Downing (1989) regression formula: $\log _{10} \quad P_{\mathrm{y}}=0.06+$ $0.79 \times \log _{10}(B)-0.16 \times \log _{10}\left(M_{\max }\right)+0.05 \times$ $T$, where $P_{\mathrm{y}}=$ annual production $\left(\mathrm{g}\right.$ carbon $(\mathrm{C}) \mathrm{m}^{-2}$ year $\left.{ }^{-1}\right), B=$ mean annual biomass $\left(\mathrm{g} \mathrm{C} \mathrm{m}^{-2}\right), M_{\max -}$ $=$ maximum biomass per taxon $[\mathrm{mg} \mathrm{C}$ individuals (ind.) $\left.{ }^{-1}\right]$ and $T=$ mean annual surface temperature $\left({ }^{\circ} \mathrm{C}\right)$. Daily production was estimated for every sampling occasion based on the mean temperature, mean biomass and the maximum biomass per taxon on a given sampling occasion instead of the annual values and dividing the resulting $P_{\mathrm{y}}$ value by 365 days (Majdi et al. 2017). Production during 1 month was estimated by multiplying daily production by the number of days between two consecutive sampling occasions. Total annual secondary production was calculated as the sum of the monthly values of secondary production (Reiss and Schmid-Araya 2010). This calculation yielded a description of the monthly dynamics of secondary production but was of limited use in the statistical analysis because the production in single replicates cannot be calculated. This approach was preferred over size-frequency methods because we assumed that the meiofauna community reproduces

Table 1 Methods used to calculate the biomass of the meiofauna groups

\begin{tabular}{lll}
\hline Taxon & Formula & References \\
\hline Nematodes & $\mathrm{ww}_{\mu \mathrm{g}}=L_{\mu \mathrm{m}} \times W_{\mu \mathrm{m}}^{2} / 16^{*} 10^{5}$ & Andrássy (1956) \\
Rotifers & $V_{\mathrm{mL}}=\left(L_{\mathrm{mm}} \times W_{\mathrm{mm}}^{2} * \mathrm{Pi}\right) / 6$ & Tod and Schmid-Araya (2009), Ruttner-Kolisko (1977) \\
Oligochaetes & $\mathrm{ww}_{\mathrm{mg}}=0.0035 \times L_{\mathrm{mm}}^{2,1}$ & Finogenova (1984) \\
Gastrotrichs & $V_{\mathrm{nL}}=L_{\mathrm{mm}} \times W_{\mathrm{mm}}^{2} \times 550$ & Feller and Warwick (1988) \\
Cladocerans & $\mathrm{dw}_{\mu \mathrm{g}}=2.4 \times 10^{-8} \times L_{\mu \mathrm{m}}^{2,77}$ & Dumont et al. (1975) \\
Tardigrades & $V_{\mathrm{nL}}=L_{\mathrm{mm}} \times W_{\mathrm{mm}}^{2} \times 614$ & Feller and Warwick (1988) \\
Copepods Cyclopoida & $\mathrm{dw}_{\mu \mathrm{g}}=1.1 \times 10^{-7} \times L_{\mu \mathrm{m}}^{2,59}$ & Dumont et al. (1975) \\
Copepods Harpacticoida & $\mathrm{dw}_{\mu \mathrm{g}}=12.51 \times L_{\mathrm{mm}}^{4,4}$ & Dumont et al. (1975) \\
Copepods Nauplii & $\mathrm{dw}_{\mu \mathrm{g}}=1.1 \times 10^{-5} \times L_{\mu \mathrm{m}}^{1,89}$ & Dumont et al. (1975) \\
Ostracods & $V_{\mathrm{nL}}=L_{\mathrm{mm}} \times W_{\mathrm{mm}}^{2} \times 450$ & Feller and Warwick (1988) \\
Microturbellarians & $V_{\mathrm{nL}}=L_{\mathrm{mm}} \times W_{\mathrm{mm}}^{2} \times 550$ & Feller and Warwick (1988) \\
Chironomids & $\mathrm{dw}_{\mathrm{mg}}=0.0018 \times L^{2.617}$ & Benke et al. (1999) \\
\hline
\end{tabular}


continuously through self-fertilization or parthenogenesis, thus lacking any discrete cohorts (Majdi et al. 2017). Moreover, it was chosen because it enables an unbiased statistical correlation of secondary production with seasonality due to the including of temperature as a covariate and yields coefficients of variation for inter- and intrahabitat comparisons lower than those of other methods (Butkas et al. 2011; Majdi et al. 2017).

\section{Statistical analysis}

All graphs were created using SigmaPlot (Systat Software version 11). A Kruskal-Wallis rank sum test was performed to examine whether microhabitat influenced the mean annual abundance, biomass and secondary production of the total meiofauna. Dunn's multiple-comparison test was used as a post hoc test (Dinno 2015) because of differences in the sample sizes from the different microhabitats. A Friedman test was used to evaluate the influence of the sampling date on total meiofaunal abundance and biomass in the microhabitats. Nonparametric tests were used because of the non-normal distribution of the data (ShapiroWilk test $p<0.05$ ). To avoid an inflated type I error by multiple comparison of data, $p$ values were adjusted based on the Holm-Bonferroni sequential correction procedure. The statistical analysis was performed using the computational environment $R$ version 3.2.3 (R Development Core Team 2016) and Dunn's test using the $\mathrm{R}$ package dunn.test (Dinno 2017). The influence of environmental factors on the density distribution of meiofaunal organisms in the four microhabitats over the sampled year was assessed according to a canonical ordination analysis (CANOOCO, version 4.5) of $\log (x+1)$-transformed data. As overarching factors, $\mathrm{O}_{2}$, temperature, $\mathrm{pH}$, conductivity, $\mathrm{NO}_{3}$ and $\mathrm{PO}_{4}$ were considered. Chl-a, AFDM, as well as the number of protozoans and bacteria were designated as microhabitat-specific factors. First, a detrended correspondence analysis (DCA) was performed in which the total inertia was 0.897 . Based on a value of $<2.6$, a predominance of linear group response curves was assumed (ter Braak 1994) and a redundancy analysis (RDA) was performed. The statistical significance of the accompanying factors was assessed using Monte Carlo permutations (999 unrestricted permutations, $\alpha=0.05$ ).
All data are given $\mathrm{m}^{-2}$ substrate surface (e.g., leaf surface or sediment area). Due to differences in the general composition of the microhabitats (sediment with a predominantly " $3 \mathrm{D}$ " structure, the three surface habitats with a "2D" structure), some limitations in the sampling strategy are obvious. In the direct comparison of the microhabitats, these limitations lead to an underrepresentation of the sediment because it is the only microhabitat that is not sampled entirely but only the upper $2 \mathrm{~cm}$. As we want to enable a first insight into the meiofaunal community on four different microhabitats of one single stream reach in this study, we decided to make this compromise.

\section{Results}

A summary of the physicochemical values and abundances of protozoans and bacteria in the four microhabitats of the Furlbach stream is provided in Table 2. For a detailed annual cycle of those values, please refer to Brüchner-Hüttemann et al. (2019).

Note that in January, February and March 2017 macrophyte sampling and in March and April 2017 leaf litter sampling were not possible because there were not enough plants/leaves to allow an adequate number of samples to be collected.

In total, ten main groups of meiofauna have been identified in the Furlbach: nematodes, rotifers, gastrotrichs, tardigrades, copepods and their nauplii larvae, oligochaetes, microturbellarians, ostracods, cladocerans and chironomids. In the sediment, nine of these ten groups (all except cladocerans) and in the other habitats all ten taxa were found during the 1-year sampling period.

Seasonal patterns in the microhabitats

The annual mean values of meiofaunal abundance, biomass and secondary production were significantly dependent on the particular microhabitat (KruskalWallis H-test all tested groups $p<0.001$, Table 3). All three parameters were 7-14 times and thus significantly higher in sediment and on dead wood than on macrophytes and leaf litter (Dunn's test all tested pairs $p<0.01$, Fig. 2a-c).

A significant seasonal pattern described the meiofaunal abundance in sediment (Friedman test $p=0.012$; Table 4), with peaks in spring/early 
Table 2 Annual range and mean $\pm \mathrm{SD}(n=13)$ values of the physicochemical parameters, Chl-a and AFDM values and abundances of protozoans and bacteria in the four microhabitats of the Furlbach stream measured monthly from April 2016 to April 2017
For Chl-a, AFDM, protozoans and bacteria on macrophytes $n=10$ and on leaf litter $n=11$

\begin{tabular}{|c|c|c|c|}
\hline & & Range & Annual mean $( \pm \mathrm{SD})$ \\
\hline \multicolumn{2}{|l|}{ Temperature $\left({ }^{\circ} \mathrm{C}\right)$} & $5.9-11.3$ & $8.6 \pm 1.7$ \\
\hline \multicolumn{2}{|l|}{$\mathrm{pH}$} & $7.3-7.5$ & $7.4 \pm 0.1$ \\
\hline \multicolumn{2}{|l|}{$\mathrm{O}_{2}\left(\mathrm{mg} \mathrm{L}^{-1}\right)$} & $7.4-10.3$ & $8.3 \pm 0.8$ \\
\hline \multicolumn{2}{|l|}{ Conductivity $\left(\mu \mathrm{S} \mathrm{cm}^{-1}\right)$} & $357-401$ & $383 \pm 12$ \\
\hline \multicolumn{2}{|l|}{ Flow velocity $\left(\mathrm{m} \mathrm{s}^{-1}\right)$} & $0.2-0.4$ & $0.3 \pm 0.1$ \\
\hline \multicolumn{2}{|l|}{$\mathrm{NO}_{3}\left(\mathrm{mg} \mathrm{L}^{-1}\right)$} & $12.6-14.7$ & $13.9 \pm 0.6$ \\
\hline \multicolumn{2}{|l|}{$\mathrm{PO}_{4}\left(\mu \mathrm{g} \mathrm{L}^{-1}\right)$} & $21.0-43.1$ & $35.1 \pm 6.2$ \\
\hline \multirow[t]{4}{*}{ Chl-a $\left(\mu \mathrm{g} \mathrm{cm}^{-2}\right)$} & Sediment & $4.2-213.2$ & $37.5 \pm 59.6$ \\
\hline & Dead wood & $0.3-6.2$ & $2.2 \pm 1.9$ \\
\hline & Macrophytes & $0.0005-0.09$ & $0.04 \pm 0.03$ \\
\hline & Leaf litter & $0.01-0.11$ & $0.04 \pm 0.03$ \\
\hline \multirow[t]{4}{*}{$\operatorname{AFDM}\left(\mu \mathrm{g} \mathrm{cm}^{-2}\right)$} & Sediment & $1.9-9.5$ & $6.4 \pm 2.3$ \\
\hline & Dead wood & $1.3-4.0$ & $2.5 \pm 0.8$ \\
\hline & Macrophytes & $0.6-1.6$ & $0.9 \pm 0.3$ \\
\hline & Leaf litter & $3.6-5.7$ & $4.7 \pm 0.8$ \\
\hline \multirow[t]{4}{*}{ Protozoans (ind. $\mathrm{cm}^{-2}$ ) } & Sediment & $3-1933$ & $522 \pm 697$ \\
\hline & Dead wood & $119-12,102$ & $2995 \pm 3210$ \\
\hline & Macrophytes & $30-346$ & $115 \pm 94$ \\
\hline & Leaf litter & $187-616$ & $381 \pm 136$ \\
\hline \multirow[t]{4}{*}{ Bacteria (ind. $\mathrm{cm}^{-2}$ ) } & Sediment & $2.9 \times 10^{5}-2.9 \times 10^{6}$ & $1.6 \times 10^{6} \pm 1.1 \times 10^{6}$ \\
\hline & Dead wood & $3.4 \times 10^{5}-5.6 \times 10^{7}$ & $1.4 \times 10^{7} \pm 1.6 \times 10^{7}$ \\
\hline & Macrophytes & $9.7 \times 10^{5}-5 \times 10^{6}$ & $2.3 \times 10^{6} \pm 1.4 \times 10^{6}$ \\
\hline & Leaf litter & $7.1 \times 10^{5}-4.9 \times 10^{6}$ & $2.6 \times 10^{6} \pm 1.4 \times 10^{6}$ \\
\hline
\end{tabular}

Table 3 Results of a Kruskal-Wallis rank sum test of the influence of habitat on annual mean abundance, biomass and daily secondary production of meiofauna

\begin{tabular}{llll}
\hline Parameter & $\chi^{2}$ & $d f$ & $p$ \\
\hline Abundance & 32.79 & 3 & $<0.001$ \\
Biomass & 29.65 & 3 & $<0.001$ \\
Secondary production & 30.90 & 3 & $<0.001$
\end{tabular}

The $\chi^{2}$-value, the degrees of freedom $(d f)$ and the $p$ value are shown

summer 2016/2017 [up to $\sim 6 \times 10^{5}\left( \pm 2.7 \times 10^{5}\right)$ ind. $\mathrm{m}^{-2}$ in May/June 2016] and lower values over the rest of the sampling period [lowest abundance in December 2016: $6.1 \times 10^{4}\left( \pm 2.3 \times 10^{4}\right)$ ind. $\mathrm{m}^{-2}$, Fig. 2d]. Meiofaunal abundances on dead wood peaked several times during the year but were highest in September and November $2016\left[\sim 4.0 \times 10^{5}\right.$ $\left( \pm 5.6 \times 10^{5}\right)$ and $4.2 \times 10^{5}\left( \pm 3.9 \times 10^{5}\right)$ ind. $\mathrm{m}^{-2}$. Lowest density in this microhabitat was also found in December $2016\left[2.4 \times 10^{4}\left( \pm 1.8 \times 10^{4}\right)\right.$ ind. $\mathrm{m}^{-2}$ ]. On the surface of macrophytes, densities ranged between $1.0 \times 10^{4}\left( \pm 3.1 \times 10^{3}\right)$ ind. $\mathrm{m}^{-2}$ in July 2016 and $2.5 \times 10^{4}\left( \pm 1.2 \times 10^{4}\right)$ ind. $\mathrm{m}^{-2}$ in September 2016. A significant seasonal pattern in meiofaunal abundance was determined for leaf litter (Friedman test $p=0.008$; Table 3), with lower values occurring between July and November 2016 than during the other months $\left[<1.2 \times 10^{4}\right.$ ind. $\mathrm{m}^{-2}$ vs. up to $1.8 \times 10^{4}\left( \pm 1.2 \times 10^{4}\right)$ ind. $\mathrm{m}^{-2}$ in January 2017 and $4.7 \times 10^{4}\left( \pm 2.5 \times 10^{4}\right)$ ind. $\mathrm{m}^{-2}$ in April 2016].

A significant seasonal pattern in meiofaunal biomass was determined for three of the four habitats: sediment, macrophytes and leaf litter (Friedman test for all three groups $p<0.05$; Table 4). In sediment, the biomass values (Fig. 2e) ranged between 30.3 $( \pm 27.8) \mathrm{mg} \mathrm{dw} \mathrm{m} \mathrm{m}^{-2}$ (August 2016) and 328.4 ( \pm 145.6) $\mathrm{mg} \mathrm{dw} \mathrm{m}^{-2}$ (May 2016) and on dead wood between $9.1( \pm 17.7) \mathrm{mg} \mathrm{dw} \mathrm{m}^{-2}$ (December 2016) and $448.4( \pm 301.2) \mathrm{mg} \mathrm{dw} \mathrm{m}^{-2}$ (June 2016). The range on macrophytes was between $1.7( \pm 1.8) \mathrm{mg} \mathrm{dw}$ 
Fig. 2 a-c Annual mean ( $\pm \mathrm{SD}$ ) abundance (Ind. $\mathrm{m}^{-2}$ ) (a), biomass (mg dw $\mathrm{m}^{-2}$ ) (b) and daily secondary production $(\mathrm{mg}$ carbon (C) $\mathrm{m}^{-2}$ day $^{-1}$ ) (c) of meiofauna in the four habitats (sediment, dead wood, macrophytes, leaf litter) of the Furlbach from April 2016 to April 2017. Different small letters above the bars indicate significant differences between the habitats (Dunn's test, $p<0.05)$. d-f: Seasonal variations in abundance (d), biomass (e) and secondary production (f) of total meiofauna in the four habitats over the 13 months of the study. The mean values of four replicates are shown. From January until March 2017 the sampling of macrophytes and from February until April 2017 the sampling of leaf litter were not possible. Data in all figure parts are shown on a logarithmic scale

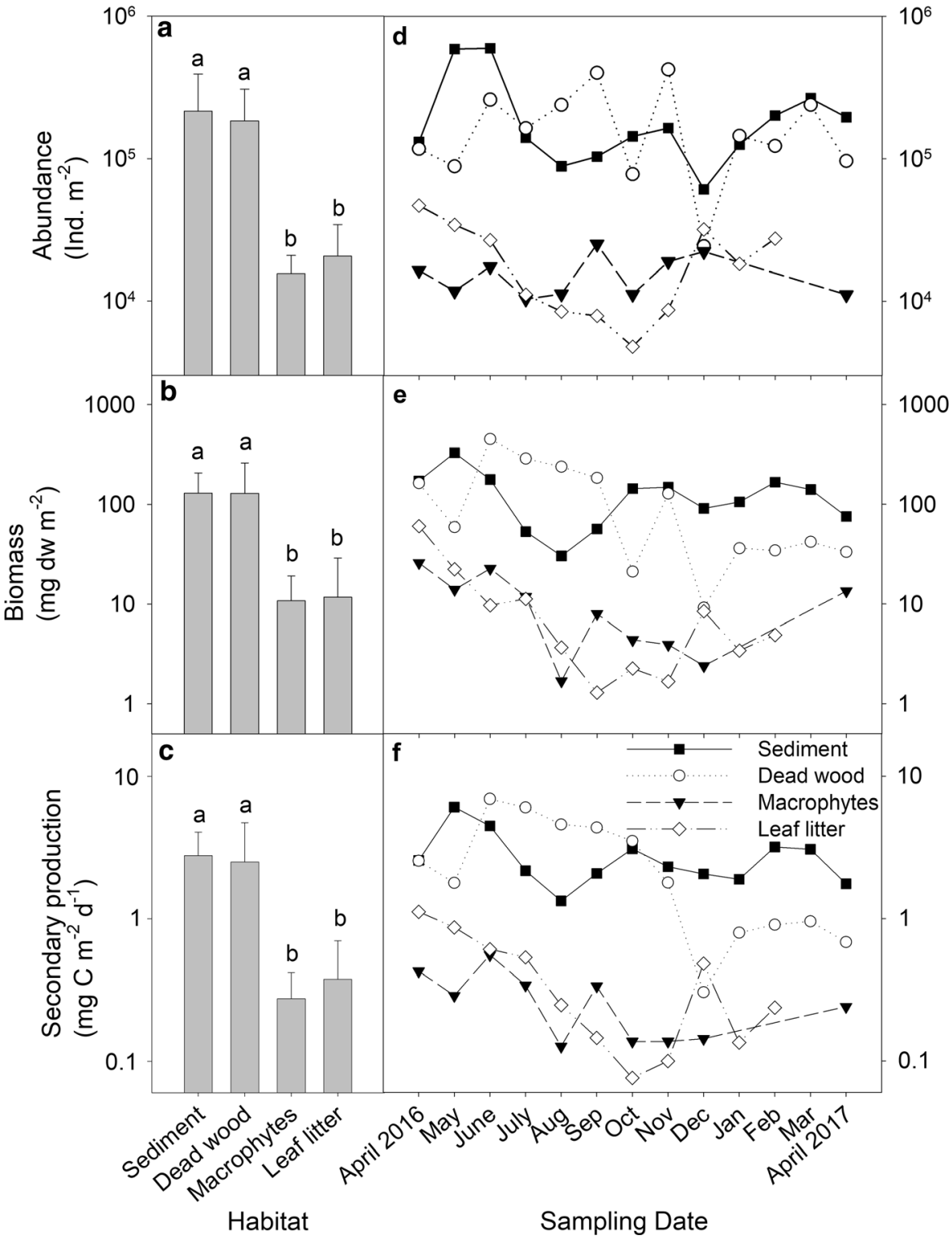

$\mathrm{m}^{-2}$ (August 2016) and $25.7( \pm 12.9) \mathrm{mg} \mathrm{dw}^{-2}$ (April 2016) and that on leaf litter between 1.3 ( \pm 1.0$)$ $\mathrm{mg} \mathrm{dw} \mathrm{m}{ }^{-2}$ (September 2016) and $60.4( \pm 47.5) \mathrm{mg}$ $\mathrm{dw} \mathrm{m}^{-2}$ (April 2016).

Due to the formula used to calculate the secondary production of meiofauna, which is directly dependent on biomass, the seasonal dynamics of secondary production followed those of biomass. The daily secondary production of all meiofaunal organisms in sediment reached a peak of $6.1 \mathrm{mg} \mathrm{C} \mathrm{m}^{-2}$ day $^{-1}$ in May 2016 (Fig. 2f) but was the lowest in August 2016, when it declined to $1.3 \mathrm{mg} \mathrm{C} \mathrm{m}^{-2}$ day $^{-1}$. On dead wood, daily meiofaunal secondary production was highest in June 2016 (7.0 $\mathrm{mg} \mathrm{C} \mathrm{m}^{-2}$ day $^{-1}$ ) and lowest in December $2016\left(0.3 \mathrm{mg} \mathrm{C} \mathrm{m}^{-2}\right.$ day $\left.^{-1}\right)$. On the surface of macrophytes, daily secondary production ranged from $0.1 \mathrm{mg} \mathrm{C} \mathrm{m}^{-2} \mathrm{day}^{-1}$ (August 2016) to $0.6 \mathrm{mg} \mathrm{C} \mathrm{m}^{-2}$ day $^{-1}$ (June 2016) and on leaf litter from $0.1 \mathrm{mg} \mathrm{C} \mathrm{m}^{-2}$ day $^{-1}$ (October 2016) to $1.1 \mathrm{mg} \mathrm{C}$ $\mathrm{m}^{-2}$ day $^{-1}$ (April 2016). 
Table 4 Results of the Friedman test on the influence of the sampling date on total meiofaunal abundance and biomass at the four microhabitats (sediment, dead wood, macrophytes and leaf litter)

\begin{tabular}{lrrllllll}
\hline Habitat & \multicolumn{3}{l}{ Abundance } & & & \multicolumn{3}{l}{ Biomass } \\
\cline { 2 - 4 } \cline { 7 - 8 } & $\chi^{2}$ & $d f$ & $p$ & & $\chi^{2}$ & $d f$ & $p$ \\
\hline Sediment & 25.74 & 12 & 0.012 & & 25.32 & 12 & 0.013 \\
Dead wood & 14.01 & 12 & n.s. & & 16.74 & 12 & n.s. \\
Macrophytes & 7.31 & 9 & n.s. & & 22.2 & 9 & 0.008 \\
Leaf litter & 23.77 & 10 & 0.008 & & 24.68 & 10 & 0.005 \\
\hline
\end{tabular}

The $\chi^{2}$-value, degrees of freedom $(d f)$ and $p$ value are reported. n.s $=$ not significant $(p>0.05)$

Contributions of the microhabitats to secondary production

Total annual secondary production by meiofauna in the four investigated microhabitats of the Furlbach during the sampling period was $2.29 \mathrm{~g} \mathrm{C} \mathrm{m}^{-2}$ year $^{-1}$. Organisms in sediment contributed $48 \%(1.10 \mathrm{~g} \mathrm{C}$ $\mathrm{m}^{-2}$ year $\left.^{-1}\right)$, those on dead wood $43 \%\left(0.98 \mathrm{~g} \mathrm{C} \mathrm{m}^{-2}\right.$ year $\left.^{-1}\right)$, on leaf litter $5 \%\left(0.12 \mathrm{~g} \mathrm{C} \mathrm{m}^{-2}\right.$ year $\left.^{-1}\right)$, and on macrophytes $4 \%\left(0.08 \mathrm{~g} \mathrm{C} \mathrm{m}^{-2}\right.$ year $^{-1}$, Fig. 3a).
Over the sampled year, highest share on monthly secondary production was at nine sampling dates contributed by organisms in sediment (up to $76 \%$ in March 2017) and at four sampling dates by organisms on dead wood (up to $73 \%$ in August 2016, Fig. 3a).

In regard to the area that was covered by the different microhabitats, the percent contributions of the microhabitats to secondary production of the stream changed (Fig. 3b). Organisms in sediment contributed $80 \%$ to total annual secondary production, those on dead wood $14 \%$, on macrophytes $4 \%$ and on leaf litter $2 \%$. Over the year at 12 sampling dates, sediments meiofauna contributed most to monthly secondary production (up to $95 \%$ in January, February and March 2017). In June 2016, organisms on the surface of macrophytes contributed most to monthly secondary production $(44 \%)$.

Factors influencing meiofaunal density distribution in the microhabitats

Overall, the RDA explained $47.7 \%$ of the meiofaunal density distribution (Table 5). Axis 1 accounted for $35.1 \%$ (species-environment correlation $=0.75$ ), mostly because of the correlation between AFDM,

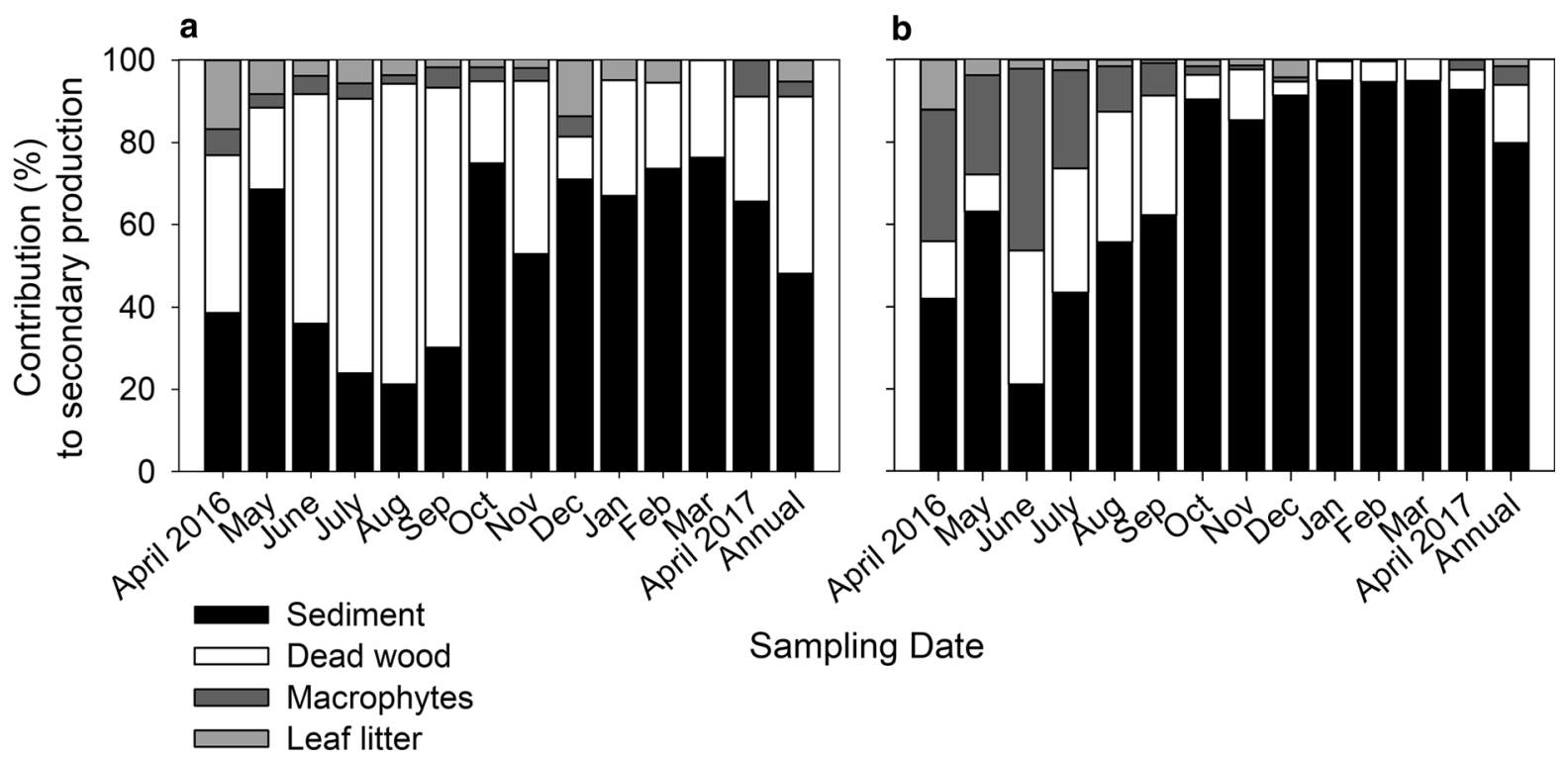

Fig. 3 The contribution (\%) of the four habitats (sediment, dead wood, macrophytes, leaf litter) to the monthly secondary production of the Furlbach from April 2016 to April 2017 in relation to (a) the habitat area and (b) the stream area covered by the specific habitat. The column "annual" shows the \%- contribution of the habitats to total annual secondary production and as the sum of monthly production, whereby in (b) these values are shown in relation to the annual mean cover ratio of the habitats 
Table 5 Statistical summary of the redundancy analysis of 47 habitat-specific samples $(\log x+1$-transformed abundances of meiofaunal groups) and nine biotic and abiotic factors

\begin{tabular}{|c|c|c|c|c|c|}
\hline Axes & 1 & 2 & 3 & 4 & Total variance \\
\hline Eigenvalues & 0.351 & 0.072 & 0.038 & 0.009 & 1 \\
\hline Species-environment correlations & 0.754 & 0.757 & 0.583 & 0.598 & \\
\hline Cumulative percentage variance of species data & 35.1 & 42.3 & 46.1 & 46.9 & \\
\hline of species-environment relation & 73.6 & 88.6 & 96.5 & 98.3 & \\
\hline Sum of all eigenvalues & & & & & 1 \\
\hline Sum of all canonical eigenvalues & & & & & 0.477 \\
\hline
\end{tabular}

Chl-a and protozoans. Axis 2 explained 7.2\% (species-environment correlation $=0.76$ ) of this distribution, because of the correlation between bacteria and temperature.

Significant determinants of the meiofaunal density distribution were protozoans (0.16), AFDM $(\lambda=0.15)$, bacteria $(0.05)$ and Chl-a (0.04) (Monte Carlo permutation test, $p<0.05$; Table 6). All meiofaunal groups clustered on the right side of the biplot, indicating effects of AFDM and Chl-a as well as protozoans and bacteria (Fig. 4a). A plot of the microhabitat samples against the factors placed sediment and dead wood to the right, sediment toward AFDM and Chl-a, and dead wood toward bacteria and

Table 6 Results of the redundancy analysis of the effects of biotic and abiotic factors on the meiofaunal density distribution in the Furlbach

\begin{tabular}{|c|c|c|c|c|c|}
\hline \multicolumn{2}{|c|}{ Marginal effects } & \multicolumn{4}{|c|}{ Conditional effects } \\
\hline Variable & $\lambda$ & Variable & $\lambda$ & $\mathrm{P}$ & $\mathrm{F}$ \\
\hline AFDM & 0.15 & Protozoa & 0.16 & 0.001 & 10.08 \\
\hline Chl-a & 0.15 & AFDM & 0.15 & 0.002 & 7.77 \\
\hline Proto & 0.14 & Bacteria & 0.05 & 0.024 & 3.47 \\
\hline $\mathrm{Bac}$ & 0.07 & Chl-a & 0.04 & 0.031 & 3.19 \\
\hline Temperature & 0.02 & Conductivity & 0.03 & 0.104 & 2.12 \\
\hline Conductivity & 0.01 & Temperature & 0.03 & 0.139 & 1.76 \\
\hline $\mathrm{O}_{2}$ & 0.01 & $\mathrm{pH}$ & 0.02 & 0.427 & 0.91 \\
\hline $\mathrm{NO}_{3}$ & 0.01 & $\mathrm{O}_{2}$ & 0 & 0.793 & 0.44 \\
\hline $\mathrm{pH}$ & 0 & $\mathrm{NO}_{3}$ & 0 & 0.994 & 0.16 \\
\hline & & Sum of all $\lambda$ & 0.48 & & \\
\hline
\end{tabular}

The factors are listed according to their eigenvalues $(\lambda)$. Statistically significant factors are shown in bold (Monte Carlo permutation test, 999 iterations) protozoans. Leaf litter and macrophytes scored in the middle of the biplot (Fig. 4b).

\section{Discussion}

Meiofaunal distribution and seasonality in four microhabitats

In all four microhabitats, the abundance, biomass and secondary production of the meiofaunal community varied between months. Nevertheless, significant seasonal patterns in meiofaunal abundance were only present in sediment and on leaf litter; thus, our results only partly support our first hypotheses.

Annual mean meiofaunal abundance $\mathrm{m}^{-2}$ was highest in sediment, although it was not significantly different from the abundance on the surface of dead wood. The total meiofaunal abundance in the upper $2 \mathrm{~cm}$ of the Furlbachs sediment is in the same range as reported in other studies (e.g., Beier and Traunspurger 2001; Reiss and Schmid-Araya 2008; Majdi et al. 2017). A seasonal pattern, with peaks in spring, also characterizes the meiofaunal abundance in sediments of other streams (Reiss and Schmid-Araya 2008). Different abiotic parameters might alter seasonal meiofaunal occurrence in sediments as, for example, discussed for water temperature and flow fluctuations by Robertson (2000). However, in the Furlbach the flow velocity measured at the 13 sampling dates was stable around the whole year. Moreover, as shown in Fig. 4, neither the investigated meiofaunal groups are influenced by water temperature nor is meiofaunal density distribution in sediment. Rather, a bottom-up driven stimulation of the meiofaunal community was shown in the Furlbachs sediment as Chl-a and AFDM 
a

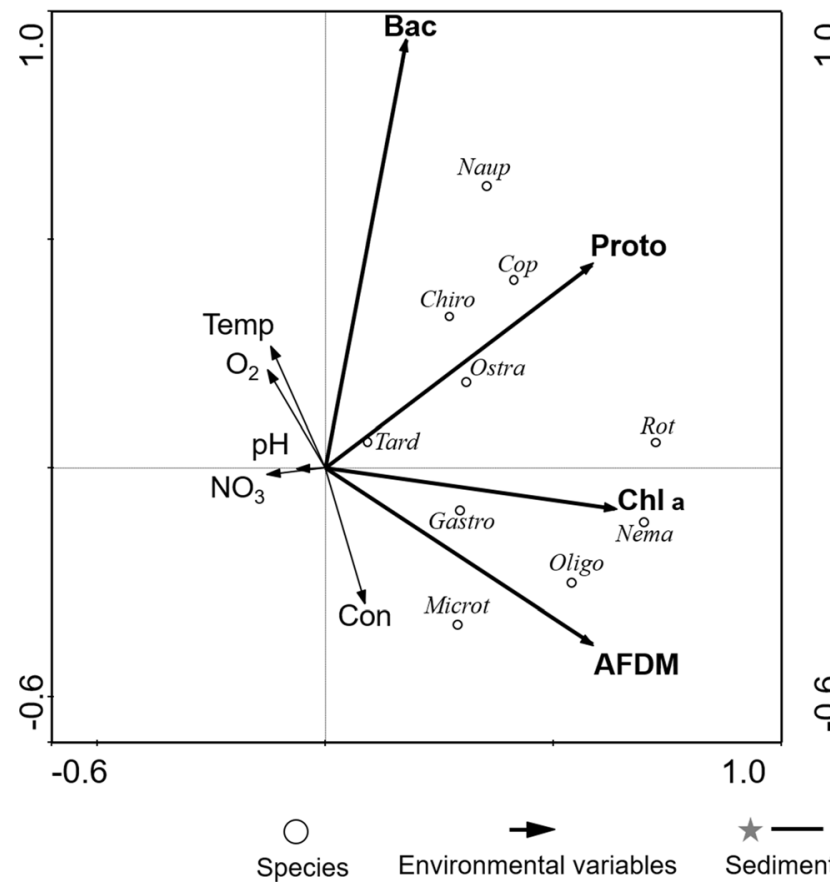

b

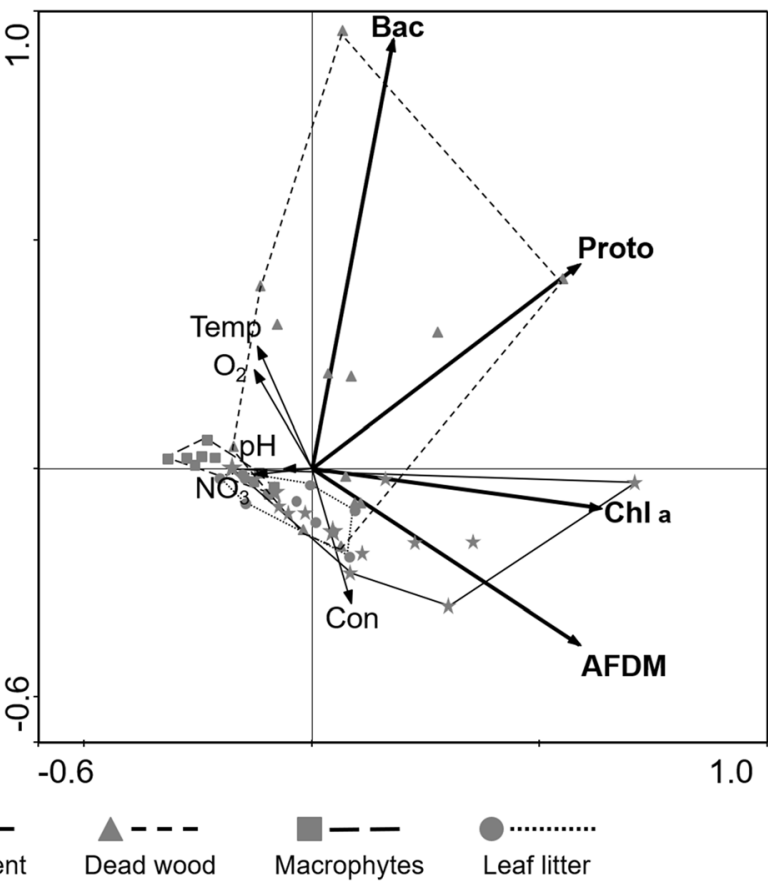

Fig. 4 RDA biplots showing (a) the density distribution of 11 meiofaunal groups under the influence of nine factors: AFDM, Chl a, Proto (protozoans), Bac (bacteria), Temp (temperature), $\mathrm{NO}_{3}, \mathrm{PO}_{4}, \mathrm{O}_{2}$ and Con (conductivity). (b) The distribution of samples grouped by habitat. Nema Nematods, Rot Rotatoria,

had the strongest impact on the meiofaunal density distribution in that microhabitat. Indeed, Chl-a as well as AFDM had their highest values in spring months.

Among the four investigated microhabitats, the annual mean abundance of meiofaunal organisms $\left(\mathrm{m}^{-2}\right)$ was second highest on the Furlbachs dead wood and annual mean biomass and secondary production $\left(\mathrm{m}^{-2}\right)$ in this microhabitat were similar to sediment. The abundance found at the Furlbachs dead wood was only slightly lower than the range of $2.2 \times 10^{4}$ to $2.2 \times 10^{5}$ ind. $\mathrm{m}^{-2}$ reported in a study of dead wood by Golladay and Hax (1995).

No effect of season on the meiofaunal community at all was found on the surface of dead wood. Brüchner-Hüttemann et al. (2019) showed that the biofilm on dead wood is highly colonized by protozoans and bacteria, organisms determined in the present study to strongly influence the meiofaunal density distribution in that microhabitat. Nevertheless, there was no seasonal pattern obvious for the unicellular community (Brüchner-Hüttemann et al. 2019)
Oligo Oligochaeta, Gastro Gastrotricha, Tard Tardigrada, Cop Copepoda, Nau Nauplii, Ostra Ostracoda, Clad Cladocera, Microt Microturbellaria, Chiro Chironomidae. Significant factors are shown in bold

which is in line with the results in the present study for the meiofaunal community.

In our first hypothesis, we predicted that strong seasonal patterns of meiofaunal abundance and biomass would also be found on macrophytes due to the seasonal variations of growth periods. However, this was the case only for biomass because the low abundances measured throughout the year on the surface of $N$. officinale in the Furlbach ruled out a significant effect of season.

Indeed, our study of the Furlbach showed a total meiofaunal abundance on the macrophyte $N$. officinale that was lower than the abundances previously determined on macrophytes at other sites (e.g., Suren 1992; Hann 1995; Tod and Schmid-Araya 2009). N. officinale has a broad-leafed structure, and according to Hann (1995), macrophyte structures impact colonization, whereby higher organismal abundances occur on plants with finely dissected leaves than on those with a broad-leafed structure. In addition, $N$. officinale exhibit chemical defense that is supposed to hinder 
biofilm growth and protozoan occurrence (Yeates and Esteban 2014) and which may cause the low abundances of meiofaunal organisms on the surface of the leaves as well.

Total annual mean meiofaunal abundance on leaf litter was $2.1 \times 10^{4}$ ind. $\mathrm{m}^{-2}$, corresponding to $4.1 \times 10^{5}$ ind. (g leaf $\left.\mathrm{dw}\right)^{-1}$. In their colonization study, Gaudes et al. (2009) found up to $\sim 2700$ organisms of the temporary meiofauna $(\mathrm{g} \text { leaf } \mathrm{dw})^{-1}$, and $\sim 400$ organisms of the permanent meiofauna ( $g$ leaf $\mathrm{dw})^{-1}$ (estimated from Fig. 2 in Gaudes et al. 2009). Thus, the densities of meiofauna on leaf litter from the Furlbach were higher. Our data indicated a significant seasonal pattern of meiofaunal abundance on leaf litter as well, with highest numbers in spring, a decrease during the summer months, and an increase again in autumn. Leaf litter input is the most important food resources in small temperate woodland streams and undergoes seasonal variations itself, as most of the allochthonous detritus enters the stream during the autumn leaf drop (Richardson 1991). In summer, the available food supply provided by leaf litter is reduced, due to intense consumption by microbes and invertebrates and to the positive correlation between the rate of decomposition and temperature (McArthur et al. 1988). Nevertheless, different experimental studies suggest that the availability of leaf material in streams influences the abundance of attached organisms not only by providing food but also by representing a complex habitat (Richardson 1991; Robertson and Milner 2001; Majdi et al. 2014). Thus, the increased decomposition of the Furlbachs leaf material during summer would explain the decreasing meiofaunal numbers, as both food and habitat became less available. In autumn, the increased leaf litter input would have replenished both the habitat and the food supply, resulting in increased meiofaunal densities. The results of the RDA revealed that meiofaunal density distribution on the surface of leaf litter in the Furlbach is not strongly influenced by the tested variables, supporting the assumption that the seasonal influences affecting the habitat itself rather affects colonization.

Generally, our results suggest a strong bottom-up stimulation of the found meiofaunal groups as well as of the meiofaunal density distribution in the Furlbach in sediment and on dead wood; thus, they only in part support our third hypothesis. Our results indicated a strong correlation of Chl-a with rotifers and nematodes, both of which are potential algal feeders. However, in Brüchner-Hüttemann and Traunspurger (2020) the nematode communities inhabiting the microhabitats of the Furlbach were investigated in detail. Here, nematodes belonging to the epistrate feeders, which are mainly algal feeder, made up $18 \%$ and $3 \%$ of the total nematode community in sediment and on dead wood, respectively. We also found that the presence of crustaceans correlated positively with that of bacteria and protozoans, i.e., the factors that strongly influenced the meiofaunal density distribution on dead wood. In the latter microhabitat, copepods, which feed on protozoans (Sanders and Wickham 1993), and their nauplii larvae made up $95 \%$ of total crustaceans.

Why Chl-a, AFDM, bacteria and protozoans exerted a strong effect on the meiofaunal density distribution in sediment and on dead wood but not on macrophytes and leaf litter is unclear, especially since, like dead wood, macrophytes and leaf litter are all water-substratum interface habitats (in contrast to the sediment as a subsurface habitat with a "3D structure"). The low meiofaunal densities on macrophytes and leaf litter surfaces in the Furlbach and the negligible influence of the other variables tested in our study suggest that factors not included in our analysis affect organismal occurrence in these microhabitats. For macrophytes and leaf litter, the negative influence of macrofaunal on meiofaunal organisms, due either to predation (Ptatscheck et al. 2015; Kreuzinger-Janik et al. 2018) or to unselective feeding behaviors (Ptatscheck et al. 2017), likely played a large role in the density distribution of meiofauna. The impact of predation/feeding in those microhabitats might have been much larger than in the sandy sediment of the Furlbach, because, as a subsurface habitat, sediment may offer protection against predation by macrofauna.

In another study of the Furlbach, the macrofaunal community was investigated over the course of a year by multi-habitat sampling (Brüchner-Hüttemann et al., under review). In the latter investigation, organismal groups like stoneflies, caddisflies, flatworms and chironomids, but also other dipterans like limoniidae, have been found. Indeed, different studies showed that those macrofaunal groups might have an influence on meiofaunal communities (Schmid-Araya and Schmid 2000; Beier et al. 2004; Majdi et al. 2015; Ptatscheck et al. 2017; Kreuzinger-Janik et al. 2018). 
However, in the present study chironomids were also counted as part of the temporal meiofauna and made up $16 \%$ of the annual mean total meiofaunal community on the surface of macrophytes and those high numbers may have resulted in great predation pressure on other meiofauna.

\section{Contribution of microhabitats to secondary production}

In line with our second hypotheses, during the sampled year the amounts of the four investigated microhabitats to monthly secondary production varied. In relation to the habitat area $\left(\mathrm{m}^{-2}\right)$ in all months, the monthly secondary production was mainly that of organisms in sediment or on dead wood. In relation to the stream area covered by the microhabitats at 12 of 13 sampling dates, organisms in sediment contributed most to monthly secondary production consistent with the relatively dominance of this microhabitat on the sampling site. Nevertheless, at one sampling date, namely in June 2016, organisms on the surface of macrophytes have the highest share on monthly secondary production. Due to a peak in the growth period at that sampling date, $85 \%$ of the investigated stream area was covered by a dense plant cushion of $N$. officinale.

Total annual secondary production in all four microhabitats of the Furlbach was $2.29 \mathrm{~g} \mathrm{C} \mathrm{m}^{-2}$ year $^{-1}$, with the organisms in sediment accounting for $1.10 \mathrm{~g} \mathrm{C} \mathrm{m}^{-2}$ year $^{-1}$ (48\%). This amount is less than that reported by Majdi et al. (2017) for the upper $5 \mathrm{~cm}$ of sediment in the same stream. The difference might be due to the higher volume to area conversion factor in their study (upper $5 \mathrm{~cm}$ ) than in our study (upper $2 \mathrm{~cm}$ ). The ca fivefold higher abundance in the sediment reported by Majdi et al. (2017) leads to a ca fourfold higher secondary production rate. Nonetheless, total annual secondary production by meiofauna in the Furlbach sediment as determined in this study was in the range of literature values, including those reported by Reiss and Schmid-Araya (2010) $\left(0.8 \mathrm{~g} \mathrm{C} \mathrm{m}^{-2}\right.$ year $^{-1}$ in Lone Oak stream and $3.7 \mathrm{~g} \mathrm{C} \mathrm{m}^{-2}$ year $^{-1}$ in Pant stream) and by Stead et al. (2005) (2.68 $\mathrm{g} \mathrm{dw} \mathrm{m}^{-2}$ year $^{-1}$, corresponding to an annual amount of $1.1 \mathrm{~g} \mathrm{C} \mathrm{m}^{-2}$ year $^{-1}$ assuming a carbon content of $40 \%$ ). But it is less than the $10.0 \mathrm{~g} \mathrm{C}$ $\mathrm{m}^{-2}$ year $^{-1}$ estimated preliminary by Marxsen (2006) for the Breitenbach stream (Germany) based on the $\mathrm{P} / \mathrm{B}$ ratio found for nematodes in that stream.

In line with our second hypotheses, in the Furlbach highest share on total secondary production $\mathrm{m}^{-2}$ was contributed by organisms in sediment. Nevertheless, with $0.98 \mathrm{~g} \mathrm{C} \mathrm{m}^{-2}$ year $^{-1}$ (43\%) the contribution of organisms on dead wood to secondary production was only slightly lower. Thus, in the Furlbach dead wood is a highly productive microhabitat; however, to our knowledge there is no other study estimating the secondary production of meiofaunal organisms in this habitat at other sites. In the Satilla River, Benke et al. (1985) found that a snag habitat was biologically the richest habitat in terms of macrofaunal diversity and production per unit of habitat surface. And in another study of the Furlbach, we found that also in terms of protozoans and bacteria the surface of dead wood provided $71 \%$ of secondary production $\mathrm{cm}^{-2}$ (Brüchner-Hüttemann et al. 2019). However, in the annual mean dead wood covered only $9 \%$ of the investigated stream area in the Furlbach and with respect to the stream area covered by the microhabitat the percentages of secondary production decreased. Nonetheless, dead wood still accounted for $14 \%$ of the total meiofaunal secondary production (this study) and for one-third of total unicellular secondary production (Brüchner-Hüttemann et al. 2019).

\section{Conclusion}

To the best of our knowledge, this investigation was the first to show the seasonal variations in the abundance, biomass and secondary production of the whole meiofaunal community at four different microhabitats of a single stream. The RDA that was performed to determine the influence of the different variables on the meiofaunal density distribution revealed that, overall, microhabitat-specific variables had a much greater influence on microhabitat communities than did factors representative of the whole stream. Thus, the impact of available food resources on the density distribution of meiofauna was shown, especially in sediment and on the surface of dead wood.

Within the course of a year, the contribution of microhabitats to secondary production in one stream might change. Nevertheless, similarly to Benke et al. (1985) and Brüchner-Hüttemann et al. (2019), our 
results show that next to the sediment, dead wood is a highly productive microhabitat not only in terms of macrofaunal and microfaunal communities but also for meiofaunal organisms. Our findings are especially relevant for low-order streams surrounded by forested areas. In those habitats dead wood is an important structural component which constantly enters the stream. Nevertheless, our results are also relevant for streams of higher order because we showed that microhabitats others than the sediment, regardless of their lower occurrence in the stream, might have a remarkable share on secondary production of the system.

Acknowledgements We thank Sascha Müller, Victoria Ronschke and Stefanie Gehner for assistance in the field and in the laboratory and Bianca Kreuzinger-Janik, Birgit Gansfort and Janina Schenk for their helpful advice. Many thanks to the reviewers and the editor for improving an earlier version of the manuscript. This research was supported by the German Federal Institute of Hydrology (BfG, Project Number: M39620304017).

Funding Open Access funding provided by Projekt DEAL.

Data availability The data that support the findings of this study are available from the corresponding author upon reasonable request.

\section{Compliance with ethical standards}

Conflict of interest The authors declare that they have no conflict of interest.

Open Access This article is licensed under a Creative Commons Attribution 4.0 International License, which permits use, sharing, adaptation, distribution and reproduction in any medium or format, as long as you give appropriate credit to the original author(s) and the source, provide a link to the Creative Commons licence, and indicate if changes were made. The images or other third party material in this article are included in the article's Creative Commons licence, unless indicated otherwise in a credit line to the material. If material is not included in the article's Creative Commons licence and your intended use is not permitted by statutory regulation or exceeds the permitted use, you will need to obtain permission directly from the copyright holder. To view a copy of this licence, visit http://creativecommons.org/licenses/by/4.0/.

\section{References}

Allan JD, Castillo MM (2007) Stream ecology: structure and function of running waters, 2nd edn. Springer, Dordrecht Andrássy I (1956) Die Rauminhalts- und Gewichtsbestimmung der Fadenwürmer (Nematoden). Acta Zool Hung 2:1-15
Arndt H (1993) Rotifers as predators on components of the microbial web (bacteria, heterotrophic flagellates, ciliates)—a review. Hydrobiologia 255/256:231-246. https:// doi.org/10.1007/BF00025844

Beier S, Traunspurger W (2001) The meiofauna community of two small German streams as indicator of pollution. J Aquat Ecosyst Stress Recov 8:387-405. https://doi.org/ 10.1023/A: 1012965424527

Beier S, Traunspurger W (2003) Temporal dynamics of meiofauna communities in two small submountain carbonate streams with different grain size. Hydrobiologia 498:107-131

Beier S, Bolley M, Traunspurger W (2004) Predator-prey interactions between Dugesia gonocephala and free-living nematodes. Freshw Biol 49:77-86. https://doi.org/10. 1046/j.1365-2426.2003.01168.x

Benke AC, Henry RL III, Gillespie DM, Hunter RJ (1985) Importance of snag habitat for animal production in southeastern stream. Fisheries 10:8-13. https://doi.org/10. 1577/1548-8446(1985)010\%3c0008:IOSHFA\%3e2.0. $\mathrm{CO} ; 2$

Benke AC, Huryn AD, Smock LA, Wallace JB (1999) Lengthmass relationships for freshwater macroinvertebrates in North America with particular reference to the southeastern United States. J N Am Benthol Soc 18:308-343. https:// doi.org/10.2307/1468447

Bergtold M, Traunspurger W (2005) Benthic production by micro-, meio-, and macrobenthos in the profundal zone of an oligotrophic lake. J N Am Benthol Soc 24:321-329. https://doi.org/10.1899/03-038.1

Borchardt MA, Bott TL (1995) Meiofaunal grazing of bacteria and algae in a piedmont stream. J N Am Benthol Soc 14:278-298. https://doi.org/10.2307/1467780

Brüchner-Hüttemann H, Traunspurger W (2020) Seasonal distribution of abundance, biomass and secondary production of free-living nematodes and their community composition in different stream micro-habitats. Nematology 22:401-422. https://doi.org/10.1163/15685411-00003313

Brüchner-Hüttemann H, Ptatscheck C, Traunspurger W (2019) Unicellular organisms on different substrates in a firstorder stream and their contribution to secondary production. Aquat Microb Ecol 83:49-63. https://doi.org/10. 3354/ame01903

Butkas KJ, Vadeboncoeur Y, Vander Zanden MJ (2011) Estimating benthic invertebrate production in lakes: a comparison of methods and scaling from individual taxa to the whole-lake level. Aquat Sci 73:153-169. https://doi.org/ 10.1007/s00027-010-0168-1

Dinno A (2015) Nonparametric pairwise multiple comparisons in independent groups using Dunn's test. Stata J 15:292-300. https://doi.org/10.1177/1536867X1501500117

Dinno A (2017) dunn.test: Dunn's test for multiple comparisons using rank sums. R package version 1.3.5. https://CRAN. R-project.org/package=dunn.test

Downing JA, Cole JJ, Duarte CM, Middelburg JJ, Melack JM, Prairie YT, Kortelainen P, Striegl RG, McDowell WH, Tranvik LJ (2012) Global abundance and size distribution of streams and rivers. Inland Waters 2:229-236. https://doi. org/10.5268/IW-2.4.502

Dumont HJ, van de Velde I, Dumont S (1975) The dry weight estimate of biomass in a selection of Cladocera, Copepoda 
and Rotifera from the plankton, periphyton and benthos of continental waters. Oecologia 19:75-97. https://doi.org/10. 1007/BF00377592

Feller RJ, Warwick RM (1988) Energetics. In: Higgins RP, Thiel $\mathrm{H}$ (eds) Introduction to the study of meiofauna. Smithsonian Institution Press, Washington DC, pp 181-196

Finogenova NP (1984) Growth of Stylaria lacustris (L.) (Oligochaeta, Naididae). Hydrobiologia 115:105-107. https:// doi.org/10.1007/BF00027902

Gansfort B, Traunspurger W, Threis I, Majdi N (2018) Wide variation in a tiny space: the microdistribution of meiobenthos in an artificial pond. Freshw Biol 63:420-431. https://doi.org/10.1111/fwb.13078

Gaudes A, Artigas J, Romaní AM, Sabater S, Muñoz I (2009) Contribution of microbial and invertebrate communities to leaf litter colonization in a Mediterranean stream. J N Am Benthol Soc 28:34-43. https://doi.org/10.1899/07-131.1

Giere O (2009) Meiobenthology: the microscopic motile fauna of aquatic sediments, 2nd rev. and extended edition. Springer, Berlin

Golladay SW, Hax CL (1995) Effects of an engineered flow disturbance on meiofauna in a North Texas Prairie stream. J N Am Benthol Soc 14:404-413. https://doi.org/10.2307/ 1467206

Gordon ND, McMahon TA, Finlayson BL, Gippel CJ, Nathan RJ (2004) Stream hydrology: an introduction for ecologists, 2nd edn. Wiley, Chichester

Hann BJ (1995) Invertebrate associations with submersed aquatic plants in a prairie wetland. UFS (Delta Marsh) Annual Report 30:78-84

Hildrew AG, Giller PS (1994) Patchiness, species interactions and disturbance in the stream benthos. In: Giller PS, Hildrew AG, Raffaelli DG (eds) Aquatic ecology: scale, pattern and process. Blackwell, Oxford, pp 21-62

Hildrew AG, Dobson MK, Groom A, Ibbotson A, Lancaster J, Rundle SD (1991) Flow and retention in the ecology of stream invertebrates. Verh Int Ver Theor Angew Limnol 24(3):1742-1747. https://doi.org/10.1080/03680770.1989. 11899062

Kreuzinger-Janik B, Kruscha S, Majdi N, Traunspurger W (2018) Flatworms like it round: nematode consumption by Planaria torva (Müller 1774) and Polycelis tenuis (Ijima 1884). Hydrobiologia 819:231-242. https://doi.org/10. 1007/s10750-018-3642-8

Leung AS, Li AOY, Dudgeon D (2012) Scales of spatiotemporal variation in macroinvertebrate assemblage structure in monsoonal streams: the importance of season. Freshw Biol 57:218-231. https://doi.org/10.1111/j.1365-2427.2011. 02707.x

Majdi N, Traunspurger W (2015) Free-living nematodes in the freshwater food web: a review. J Nematol 47:28-44

Majdi N, Boiché A, Traunspurger W, Lecerf A (2014) Predator effects on a detritus-based food web are primarily mediated by non-trophic interactions. J Anim Ecol 83:953-962. https://doi.org/10.1111/1365-2656.12189

Majdi N, Traunspurger W, Richardson JS, Lecerf A (2015) Small stonefly predators affect microbenthic and meiobenthic communities in stream leaf packs. Freshw Biol 60:1930-1943. https://doi.org/10.1111/fwb.12622
Majdi N, Threis I, Traunspurger W (2017) It's the little things that count: meiofaunal density and production in the sediment of two headwater streams. Limnol Oceanogr. 62:151-163. https://doi.org/10.1002/lno.10382

Majdi N, Schmid-Araya JM, Traunspurger W (2020) Examining the diet of meiofauna: a critical review of methodologies. Hydrobiologia 847:2737-2754. https://doi.org/10.1007/ s10750-019-04150-8

Marxsen J (2006) Bacterial production in the carbon flow of a central European stream, the Breitenbach. Freshw Biol 51:1838-1861. https://doi.org/10.1111/j.1365-2427.2006. 01620.x

McArthur JV, Barnes JR, Hansen BJ, Leff LG (1988) Seasonal dynamics of leaf litter breakdown in a Utah Alpine stream. J N Am Benthol Soc 7:44-50. https://doi.org/10.2307/ 1467830

McCauley E (1984) The estimation of the abundance and biomass of zooplankton in samples. In: Downing JA, Rigler $\mathrm{FH}$ (eds) A manual on methods for the assessment of secondary productivity in fresh waters, 2nd edn. Blackwell, Oxford, pp 228-265

Palmer MA (1990) Temporal and spatial dynamics of meiofauna within the hyporheic zone of Goose Creek, Virginia. J N Am Benthol Soc 9:17-25. https://doi.org/10.2307/ 1467930

Palmer MA, Bely AE, Berg KE (1992) Response of invertebrates to lotic disturbance: a test of the hyporheic refuge hypothesis. Oecologia 89:182-194

Palmer MA, Swan CM, Nelson K, Silver P, Alvestad R (2000) Streambed landscapes: evidence that stream invertebrates respond to the type and spatial arrangement of patches. Landsc Ecol 15:536-576

Perlmutter DG, Meyer JL (1991) The impact of a streamdwelling harpacticoid copepod upon detritally associated bacteria. Ecology 72:2170-2180. https://doi.org/10.2307/ 1941568

Peters L, Scheifhacken N, Kahlert M, Rothhaupt K-O (2005) Note: an efficient in situ method for sampling periphyton in lakes and streams. Arch Hydrobiol 163:133-141. https:// doi.org/10.1127/0003-9136/2005/0163-0133

Peters L, Wetzel MA, Traunspurger W, Rothhaupt K-O (2007) Epilithic communities in a lake littoral zone: the role of water-column transport and habitat development for dispersal and colonization of meiofauna. J N Am Benthol Soc 26:232-243. https://doi.org/10.1899/0887-3593(2007)2 6\%5b232:ECIALL\%5d2.0.CO;2

Pfannkuche O, Thiel H (1988) Sample processing. In: Higgins RP, Thiel H (eds) Introduction to the study of meiofauna. Smithsonian Institution Press, Washington DC, pp 134-145

Plante C, Downing JA (1989) Production of freshwater invertebrate populations in lakes. Can J Fish Aquat Sci 46:1489-1498. https://doi.org/10.1139/f89-191

Pottgießer T, Sommerhäuser M (1999) Referenzgewässer der Fließgewässertypen Nordrhein-Westfalens Teil 1: Kleine bis mittelgroße Fließgewässer. LUA Merkblätter 16

Ptatscheck C, Kreuzinger-Janik B, Putzki H, Traunspurger W (2015) Insights into the importance of nematode prey for chironomid larvae. Hydrobiologia 757:143-153. https:// doi.org/10.1007/s10750-015-2246-9 
Ptatscheck C, Putzki H, Traunspurger W (2017) Impact of deposit-feeding chironomid larvae (Chironomus riparius) on meiofauna and protozoans. Freshw Sci 36:796-804. https://doi.org/10.1086/694461

Ptatscheck C, Brüchner-Hüttemann H, Kreuzinger-Janik B, Weber S, Traunspurger W (2020) Are meiofauna a standard meal for macroinvertebrates and juvenile fish? Hydrobiologia 847:2755-2778. https://doi.org/10.1007/ s10750-020-04189-y

R Development Core Team (2016) R: a language and environment for statistical computing. R Foundation for Statistical Computing, Vienna, Austria. http://www.R-project.org

Rasband WS (1997-2018) ImageJ. National Institutes of Health, Bethesda, Maryland, USA. https://imagej.nih.gov/ij/

Reiss J, Schmid-Araya JM (2008) Existing in plenty: abundance, biomass and diversity of ciliates and meiofauna in small streams. Freshw Biol 53:652-668. https://doi.org/10. 1111/j.1365-2427.2007.01907.x

Reiss J, Schmid-Araya JM (2010) Life history allometries and production of small fauna. Ecology 91:497-507. https:// doi.org/10.1890/08-1248.1

Richardson JS (1991) Seasonal food limitation of detritivores in a Montane stream: an experimental test. Ecology 72:873-887. https://doi.org/10.2307/1940589

Richardson JS, Danehy RJ (2007) A synthesis of the ecology of headwater streams and their riparian zones in temperate forests. For Sci 2:131-147. https://doi.org/10.1093/ forestscience/53.2.131

Robertson AL (2000) Lotic meiofaunal community dynamics: colonisation, resilience and persistence in a spatially and temporally heterogeneous environment. Freshw Biol 44:135-174. https://doi.org/10.1046/j.1365-2761.2000. 00595.x

Robertson AL, Milner AM (2001) Coarse particulate organic matter: a habitat or food resource for the meiofaunal community of a recently formed stream. Fund Appl Limnol 152:529-541. https://doi.org/10.1127/archiv-hydrobiol/ $152 / 2001 / 529$

Robertson AL, Rundle SD, Schmid-Araya JM (2000) Putting the meio- into stream ecology: current findings and future directions for lotic meiofaunal research. Freshw Biol 44:177-183. https://doi.org/10.1046/j.1365-2427.2000. 00592.x

Ruttner-Kolisko A (1977) Suggestion for biomass calculations of plankton rotifers. Arch Hydrobiol 8:71-76

Sanders RW, Wickham SA (1993) Planktonic protozoa and metazoa: predation, food quality and population control. Mar Microb Food Webs 7:197-223

Schmid-Araya JM, Schmid PE (2000) Trophic relationships: integrating meiofauna into a realistic benthic food web. Freshw Biol 44:149-163. https://doi.org/10.1046/j.13652427.2000.00594.x

Schmid-Araya JM, Hildrew AG, Robertson AL, Schmid PE, Winterbottom J (2002) The importance of meiofauna in food webs: evidence from an acid stream. Ecology 83:1271-1285. https://doi.org/10.1890/0012-9658(2002)0 83\%5b1271:TIOMIF\%5d2.0.CO;2

Schmid-Araya JM, Schmid PE, Majdi N, Traunspurger W (2020) Biomass and production of freshwater meiofauna: a review and a new allometric model. Hydrobiologia
$847: 2681-2703$

https://doi.org/10.1007/s10750-02004261-7

Schroeder F, Traunspurger W, Pettersson K, Peters L (2012) Temporal changes in periphytic meiofauna in lakes of different trophic states. J Limnol 71:216-227. https://doi. org/10.4081/jlimnol.2012.e23

Silver P, Palmer MA, Swan CM, Wooster D (2002) The small scale ecology of freshwater meiofauna. In: Rundle SD, Robertson AL, Schmid-Araya JM (eds) Freshwater Meiofauna: biology and ecology. Backhuys Pubishers, Leiden, pp 217-239

Stead TK, Schmid-Araya JM, Hildrew AG (2003) All creatures great and small: patterns in the stream benthos across a wide range of metazoan body size. Freshw Biol 48:532-547. https://doi.org/10.1046/j.1365-2427.2003. 01025.x

Stead TK, Schmid-Araya JM, Hildrew AG (2005) Secondary production of a stream metazoan community: does the meiofauna make a difference? Limnol Oceangr 50:398-403. https://doi.org/10.4319/lo.2005.50.1.0398

Strahler AN (1952) Hypsometric (area-altitude) analysis of erosional topography. Geol Soc Am Bull 63:1117-1142. https://doi.org/10.1130/0016-7606(1952)63\%5b1117: HAAOET\% $5 \mathrm{~d} 2.0 . \mathrm{CO} ; 2$

Suren AM (1992) Meiofaunal communities associated with bryophytes and gravels in shaded and unshaded alpine streams in New Zealand. N Z J Mar Freshw 26:115-125. https://doi.org/10.1080/00288330.1992.9516507

Swan CM, Palmer MA (2000) What drives small-scale spatial patterns in lotic meiofauna communities? Freshw Biol 44:109-121. https://doi.org/10.1046/j.1365-2427.2000. 00587.x

Teiwes M, Bergtold M, Traunspurger W (2007) Factors influencing the vertical distribution of nematodes in sediments. J Freshw Ecol 22:429-439. https://doi.org/10.1080/ 02705060.2007.9664173

ter Braak CJF (1994) Canonical community ordination. Part I: basic theory and linear methods. Écoscience 1:127-140. https://doi.org/10.1080/11956860.1994.11682237

Tod SP, Schmid-Araya JM (2009) Meiofauna versus macrofauna: secondary production of invertebrates in a lowland chalk stream. Limnol Oceanogr 54:450-456. https://doi. org/10.4319/lo.2009.54.2.0450

Townsend RC (1989) The patch dynamics concept of stream community ecology. J N Am Benthol Soc 8:36-50

Traunspurger W (2000) The biology and ecology of lotic nematodes. Freshw Biol 44:29-45. https://doi.org/10. 1046/j.1365-2427.2000.00585.x

Vannote RL, Minshall GW, Cummins KW, Sedell JR, Cushing CE (1980) The river continuum concept. Can J Fish Aquat Sci 37:130-137. https://doi.org/10.1139/f80-017

Weber S, Traunspurger W (2015) The effects of predation by juvenile fish on the meiobenthic community structure in a natural pond. Freshw Biol 60:2392-2409. https://doi.org/ 10.1111/fwb. 12665

Weber S, Traunspurger W (2016) Influence of the ornamental red cherry shrimp Neocaridina davidi (Bouvier, 1904) on freshwater meiofaunal assemblages. Limnologica 59:155-161. https://doi.org/10.1016/j.limno.2016.06.001

Weber S, Traunspurger W (2017) Invasive red swamp crayfish (Procambarus clarkii) and native noble crayfish (Astacus 
astacus) similarly reduce oligochaetes, epipelic algae, and meiofauna biomass: a microcosm study. Freshw Sci 36:103-112. https://doi.org/10.1086/690556

Weitere M, Erken M, Majdi N, Arndt H, Norf H, Reinshagen M, Traunspurger W, Walterscheid A, Wey JK (2018) The food web perspective on aquatic biofilms. Ecol Monogr 88:543-559. https://doi.org/10.1002/ecm.1315

Wohl E (2017) The significance of small streams. Front Earth Sci 11:447-456. https://doi.org/10.1007/s11707-0170647-y
Yeates AM, Esteban GF (2014) Local ciliate communities associated with aquatic macrophytes. Int Microbiol 17:31-40. https://doi.org/10.2436/20.1501.01.205

Publisher's Note Springer Nature remains neutral with regard to jurisdictional claims in published maps and institutional affiliations. 